\title{
Practical Exploration of School-Family Cooperative Education during the COVID-19 Epidemic: A Case Study of Zhenjiang Experi- mental School in Jiangsu Province, China
}

\author{
Jianping Xia
}

Zhenjiang Experimental School of Jiangsu Province, Zhenjiang 212000, Jiangsu, China

\begin{abstract}
As the country fights against the COVID-19 epidemic, "School's Out, But Class's On" has been launched in schools everywhere. In order to do a good job in school education services and minimize the impact of the epidemic on normal education and teaching, the Zhenjiang Experimental School in Jiangsu Province has closely contacted parents, carried out school-family cooperative education through school and family cooperation, and worked together to ensure students with the quality of learning during the COVID-19 epidemic, and jointly promote the all-round development of students. We used Zhenjiang Experimental School's practice during the COVID-19 epidemic as an example to explore a new path for the integration of home education and school education.
\end{abstract}

Best Evid Chin Edu 2020; 4(2):521-528.

Doi: 10.15354/bece.20.rp003.

Keywords: COVID-19 Epidemic; "School's Out, But Class's On"; School-Family Co-Education; Practice; Middle School

Correspondence to: Jianping Xia, Principal of Zhenjiang Experimental School of Jiangsu Province, Zhenjiang 212000, Jiangsu, China.Email:xwph123@163.com. 
CHOOLS and families are indispensable subjects in the healthy growth of children. Building a harmonious home-school relationship and forming a pattern of cooperative education are of great significance to the development of students. During the COVID-19 epidemic, the school's regular teaching activities could not be carried out normally, and the family became the only place for students to learn. The implementation of "School's Out, But Class's On", i.e., "School is closed, but student learning is continuing online" or "Online Home Study" (This refers to the Official Website of the Chinese Ministry of Education: http://en.moe.gov.cn/). made the family and school cooperate much closer.

Schools and families need to establish a unified goal to ensure the quality of student learning, cultivate students' autonomous learning ability, and promote the allround development of students. Guide parents to actively cooperate with the online teaching activities carried out by the school, participate in student education, create a good learning and education environment for students, and achieve student development goals.

Zhenjiang Experimental School of Jiangsu Province, through home-school cooperation, gives full play to the important role of family education in the "School's Out, But Class's On" period, guides parents to actively participate in online teaching activities and offline academic guidance, and effectively promotes students' home study To achieve healthy and happy growth of students. This study used the School-Family Coeducation practice of Zhenjiang Experimental School during "School's Out, But Class's On" as an example to explore how to integrate school education and home education during the epidemic. It ensures the quality of students' home study and promotes their comprehensive and healthy development.

\section{Meaning of School-Family Co-education}

School-Family Co-education is to cultivate students together through home education and school education, and its fundamental purpose is to promote the all-round development and healthy growth of students. Some scholars once defined School-Family Coeducation as "the principle of mutual respect, cooperation, joint efforts, and coordinated education between schools and families, teachers and parents, and both parties share the responsibility of cultivating students and jointly develop two-way, Regular and comprehensive cooperation activities to promote the healthy growth and comprehensive development of students" (Wang \& Dong, 2018).

Family education is the foundation of school education, and school education is a supplement and extension of family education. This requires families and schools to play their respective advantages to promote effective complementarities between school education and family education, and to form a joint education force (Lu \& Liu, 2019). Schools should build platforms and provide guidance for parents to participate in school education and improve parents' family education. Parents should take the initiative to learn about family education, establish a correct concept of family education, actively communicate with the school, actively participate in school management and education, and maintain consistency with school education. 
Home-school co-education, as a complementary educational behavior model and relationship model, is a valuable pursuit (Wen, 2019), which is of great significance to the cultivation of student morality and the promotion of comprehensive development. Therefore, school education should be closely integrated with family education, realize the synergy of education, provide better education methods for students, and promote better growth and development of students.

\section{Bases of School-Family Co-education}

The integration of school education and home education is an inevitable trend of modern education (Liu, 2015). Achieving School-Family Co-education requires schools to build platforms for parents and encourage parents to take an active part. During the epidemic, family education became the main form and home-school relationships were closer. Schools use the Internet to build a platform for School-Family Co-education, which not only enables teachers and parents to better communicate with their children's learning, but also provides children with better learning resources and effectively promotes School-Family Co-education.

\section{Build School-Family Co-education Platform}

The school establishes a platform for students' online learning and the School-Family Co-education network platform through the provincial, municipal and school platforms. In addition, it implements remote interaction with parents through the public communication platform QQ and WeChat group, and fully implements the Internet-based School-Family Co-education.

\section{Use Public Platforms to Build Student Online Learning Platforms.}

During the epidemic, the family became the only place for students to learn. The school set up an online learning platform for students through the provincial, municipal and school platforms. Guide students to realize online learning by watching Zhenjiang Public Education Platform "Zhenjiang Wisdom Education Platform" and Jiangsu Public Education Platform "Jiangsu Famous Teachers Air Classroom”.

In addition, in response to students' learning and answering questions, the Jiangsu Province Teaching and Research Office organizes teachers to provide students with "one-on-one" online learning answering and tutoring through video calls every day from 15:00 to 16:30. On the public education platform in Jiangsu Province, teachers are used to provide students with question answering services in the form of teachers' selfselection.

\section{Create A School-Family Co-Education Network Learning Platform Using A Common Platform.}

The public learning platform not only provides platform support for students' online learning during the epidemic, but also provides a module for School-Family Coeducation and provides an online learning platform for School-Family Co-education. 


\section{Use Public Communication Platform to Realize Remote and Timely Com- munication.}

The head teachers of each class of the school organize the creation of parent QQ and WeChat groups, and the group members are the parents of each student, teachers of each subject, and head teachers. During the epidemic, teachers posted learning tasks in groups daily and instructed students on home study methods or related educational information. Parents can use QQ or WeChat groups to communicate student learning trends, problems or solutions encountered, so that teachers and parents, parents and parents can achieve remote interaction through QQ and WeChat. At the same time, the homeroom teacher can regularly push the epidemic prevention knowledge and other School-Family Co-education training resources during the epidemic through the WeChat public account of the class for parents and teachers to learn in time. This can effectively raise parents and teachers' awareness of School-Family Co-education, effectively promote the synergy of education, and provide students with better education methods.

\section{School-Family Co-education Resources}

The construction of home-school resources requires not only school resources, but also parent resources to jointly build home-school cooperative education resources. During the epidemic, the school relied on the municipal and provincial education bureaus to develop online learning resources. At the same time, the school used classes as a unit to dig deeper into parent resources and enrich students' home learning resources.

\section{Develop Online Learning Resources by Relying on Provincial and Munic- ipal Forces.}

During the epidemic, the Jiangsu Provincial Teaching and Research Office organized provincial 8th grade students, special senior teachers, senior teachers, and city-level discipline leading teachers to record review sessions. For the courses of other grades, the Jiangsu Province Department of Education organized subject teaching experts to launch a one-week course catalog and broadcast schedule for each subject in each grade and class based on the content of the first week of the spring semester, so that students can follow the catalog with options for online learning.

At the same time, for the online learning of junior high school students in Zhenjiang, Zhenjiang Education Bureau organized the backbone teachers in the city to record synchronous classroom teaching videos covering all classes and grades (preschool education regardless of age) in units of class hours. The city's public education platform "Zhenjiang Wisdow Education" was launched.

In addition, the school will digitize school-based learning resources based on study guides to provide more targeted learning resources for school students.

\section{With the Help of Parents, Promote the Rationalization of Students' Home Study Content.}


As a special social resource, parents are essential for optimizing curriculum construction. Especially during the epidemic, parents have become the most important study guides and companions for students, and have played an important role in the learning effect of students during their homes. The diversification of online resources brings abundant resource guarantees for students 'home study, but whether it is suitable for the students' study rules and whether the student's home study can be completed requires the parents 'timely guidance and evaluation of the students' academic work. Parents publish online teaching plans and student learning plans through schools to understand students' learning requirements and progress, and provide offline guidance, supervision and evaluation for students' academic learning, so as to work with class teachers and homeroom teachers to develop online learning resources and plan.

At the same time, the school digs into the resources of parents, launches "one thing a week", and implements family moral education practices. Each class launches a home network education activity on the theme of reading, calligraphy and painting, family labor, etc., combining students' moral education with family education. This promotes students to correctly understand the relationship between people, society and nature under the guidance of their parents, respects the objective world, acts scientifically and rationally, and makes students grow healthier.

\section{School-Family Co-education Measures during the Ep- idemic}

The home study of students is completely different from the study of students during school after the start of school, and requires the cooperation of homeroom teacher, classroom teachers and parents. Therefore, during the epidemic, schools have formulated different measures for homeroom teachers, classroom teachers, and parents to ensure the smooth implementation of School-Family Co-education.

\section{Homeroom Teacher Level Work Measures}

1. Establish and manage class learning and communication platforms. Class learning and communication platforms can be established through platforms such as WeChat group and QQ group.

2. Daily statistics of student observations and assignments. Each day, after each homeroom teacher and the teacher understands the completion of the homework submission, fill in the "Statistics Form for Online Learning of Students in Zhenjiang Experimental School" and submit it to the director in charge of teaching for the corresponding grade. This folder collects statistics on online learning of students in this grade and submits statistics to relevant personnel of the Academic Affairs Office.

\section{Working-Teacher Measures}


1. Organize teaching seminars. For the city's education bureau to organize the backbone teachers of the city, the recorded classroom teaching video content of each subject is synchronized, and the team leader organizes teachers in the group to conduct online teaching seminars and make relevant records at least once a week.

2. Develop student exercises. Teachers in accordance with the school's daily curriculum schedule for each grade, watch the online course with students, and make notes at the same time. And according to the online teaching content, develop weekly subject practice in advance, arrange only the basic questions, do detailed answers, and send them to the QQ groups in each class.

3. Help students answer questions. If students still have questions after watching the video, they can send them point-to-point to the corresponding subject teachers, and the teachers will answer the questions on the day (the questions asked by the students before 18:00 pm on the day).

4. Review student work. Teachers in the class select $30 \%$ of the students in the class daily to submit assignments. After the student's point-to-point to the corresponding subject teachers, the teachers make comments, feedback and correct comments or suggestions to explain the students' problems. Among them, the form of student assignments can be in the form of electronic manuscripts, printed manuscripts, or direct answers to questions in the assignment book. 30\% of students submitting assignments should be selected alternately. While caring for key students, it is necessary to ensure that all students have the experience of submitting assignments in the short term.

5. Statistics of teachers' teaching. The preparation team completes the "Statistical Table of Online Teaching, Teaching and Research Work" of the preparation team, and reports it to the teaching director before 5:00 pm on Sunday.

\section{Parental Measures}

1. Instruct students to learn about epidemic situation. During the epidemic, parents should guide their children to pay attention to the official notification and authoritative broadcast of the pneumonia epidemic of COVID-19 infection, and guide children to learn relevant epidemic prevention knowledge and do personal health protection through special education on "epidemic".

2. Urge your child to actively develop online learning. Parents should cooperate with schools and teachers to urge their children to use Zhenjiang Smart Education Platform to conduct online learning. The main tasks are as follows:

- Refer to the daily curriculum schedules of all grades issued by the school to arrange study and life, and promote the development of good study habits and living habits of students.

- Guide and urge children to complete the learning videos, homework, teaching plans, homework explanation videos and homework answers for each subject in the learning platform on a daily basis. When in doubt, parents guide students to ask questions to the teacher through QQ. 
- Parents with tutoring ability can provide tutoring to students' learning, and guide students who have the ability to learn autonomously through the "famous teacher air classroom" in Jiangsu Province.

- Upload student assignments and cooperate with homeroom teacher to complete statistics of children's online learning every day.

- Guide children to develop personal hobbies and implement family moral education practices while studying.

\section{Concluding Remarks}

"School's Out, But Class's On" is a challenge to both school education and family education. It not only requires schools to strengthen the guidance of students 'online learning, and to do a good job in the service of students' home study. It also needs the cooperation of the family and the school to help students reasonably arrange their work schedules and home study course content, and improve the content of home study. During the epidemic, the School of Zhenjiang Experimental School in Jiangsu Province used School-Family Co-education to supplement school education and work together to promote student learning and development. It is true that when schools promote SchoolFamily Co-education during the epidemic, there are still some problems that need to be solved urgently, such as difficulties for some parents to guide students, and the implementation of homework feedback cannot be implemented. These questions will encourage schools to further think about how to better establish a home-school linkage mechanism.

\section{References}

Liu, J. On the combination of elementary school education and family education. Reading Writing, 16: 360

Lu, B., Liu, J. (2019) Home-school interaction and cohesion to create a harmonious and high-quality education. Basic Edu Referen, 18: 31-32

Wang, S., Dong, Y. (2018) Information technology promotes the implementation of school-family Co-education-Taking the Primary School Affiliated to Feicheng City Normal School as an example. Modern Edu, 4: 58-59.
Wen, Y. (2019) School-Family Co-education, Warm Forward-An Analysis of the Significance and Methods of Home-School Cooperation in High School. Guangdong Chenyue Education Development Co., Ltd. Guangdong Education Society Education Modernization Professional Committee". Proceedings of Teaching and Scientific Research Research and Thesis Writing Advanced Seminar (6), Guangzhou: 2-4. 
Xia. School-Family Cooperative Education during the COVID-19 Epidemic.

Received: 28 February 2020

Revised: 05 March 2019

Accepted: 11 March 2019 